\title{
THE EFFECT OF DUROC AND PIETRAIN BOARS ON GROWTH ABILITY OF PIGLETS
}

\author{
Jan Lujka¹, Pavel Nevrkla', Zdeněk Hadaš \\ ${ }^{1}$ Department of Animal Breeding, Faculty of AgriSciences, Mendel University in Brno, Zemědělská 1, 61300 Brno,
Czech Republic
}

Link to this article: https://doi.org/10.11118/actaun.2021.050

Received: 23. 6. 2021, Accepted: 6. 9. 2021

To cite this article: LUJKA JAN, NEVRKLA PAVEL, HADAŠ ZDENĚK. 2021. The Effect of Duroc and Pietrain Boars on Growth Ability of Piglets. Acta Universitatis Agriculturae et Silviculturae Mendelianae Brunensis, 69(5): 563-568.

\begin{abstract}
The aim of the experiment was to evaluate the effect of Duroc, Pietrain and Duroc x Pietrain terminal boars on individual live weight of piglets and average daily gain of piglets from birth to weaning. The effect of sex was also taken into account in the observation. A total of 306 piglets were evaluated. The experiment proved, that terminal boar significantly affects $(p<0.001)$ birth weight of piglets, their live weight at the age of 14 days and at weaning. Statistically significant effect of terminal boar was also proved for average daily gain from birth to the age of 14 days and average daily gain from birth to weaning. As demonstrated, the piglets of Duroc and Pietrain boars reached higher live weights in all the observed intervals than the piglets of Duroc x Pietrain hybrid combination boar. The same trend was observed for the values of average daily gain in piglets.
\end{abstract}

Keywords: terminal boar, sex of piglets, live weight of piglets, growth of piglets

\section{INTRODUCTION}

Growth ability of piglets from birth to slaughter is affected by many factors. In general, producers of pigs for slaughter focus on birth weight of piglets and their weaning weight (Surek et al., 2019). Weaning weight of piglets is determined by factors, such as birth weight and milk intake. It is also associated with parameters of litter, namely size of litter and variability of birth weight. Birth weight is a result of intrauterine growth of piglets and it is considered to be one of the most important factors determining survivability of pigs (Wolter et al., 2002; Deen and Bilkei, 2004). For these reasons, the breeders aim the selection not only for the numbers of live-born piglets and the numbers of reared piglets per litter, but also for the appropriate birth weight and growth ability of piglets from birth to weaning (Haley et al., 1995). It has been documented, that heredity of birth weight in piglets, unlike the heredity of reproductive performance parameters, is very favourable with coefficient of 0.31 (Marandu et al., 2015). Correct selection of the terminal boar has then an important impact on these parameters (McCann et al., 2008). At present, pork meat is produced mainly from hybrids of three or four breeds with good growth and meat quality. By utilization of more breeds, heterosis effect is achieved, which increases performance of offspring in comparison with paternal or maternal populations (Keller et al., 2002). Selection and choice of appropriate genotypes is an important factor to achieve profitable production of piglets and slaughter pigs. A determining factor for selection of a suitable hybrid combination are the results of hybrid populations tests which are principally designed for selection of optimal individuals for specific conditions (Pedersen et al., 2019). For producers of pigs for slaughter, it is important to perform these tests in conditions of production farms, since they represent the most important form of pig production. Boars of the Duroc breed are generally used as terminal boars for their excellent growth and great meat quality with a good intramuscular fat content (Lonergan et al., 
2001; Edwards et al., 2006). The Pietrain breed is used in terminal position mainly for its excellent meat conformation. Therefore, the aim of this study was to evaluate growth intensity before weaning in 14 days intervals in piglets of Duroc, Pietrain and their hybrids, in a specific conditions of a production farm in the Czech Republic.

The aim of this experiment was to evaluate the effect of terminal boars of Duroc, Pietrain and Duroc x Pietrain, and the effect of sex in piglets on their individual birth weight, weight at the age of 14 days and at weaning. The effect of these boars on average daily gain of piglets from birth to the age of 14 days and from Day 15 to weaning was also evaluated.

\section{MATERIALS AND METHODS}

The experiment was carried out in a conventional production pig farm in the Czech Republic. It was started in winter 2020 by selection of mothers and their insemination.

\section{Animals}

All the sows were of the Large White $x$ Landrace hybrid combination. The sows were divided into three groups, each group was inseminated by a different boar. The sows included in the observation were from the first to the fourth parity with equal distribution of parities in the groups for individual boars. Insemination doses came from one insemination station and they were prepared using heterospermia for each of the terminal boar.

A total of 306 piglets were evaluated, 146 of the hybrid combination Duroc x Pietrain (D x Pn), 41 of the Duroc boar (D) and 119 of the Pietrain boar (Pn).

\section{Observation Process}

Farrowing of the sows took place within one batch in summer of 2020. One day after farrowing, the litters were standardized to the number of 11-13 piglets within individual hybrid groups. Each piglet was weighed after birth and labelled with an ear notch with individual number. Another individual weighing was carried out 14 days after birth and at weaning age of \pm 28 days. Weighing was performed using a digital hanging scale with accuracy of $0.01 \mathrm{~kg}$. Intramuscular application of iron and surgical castration of males was performed one day after birth. After weaning of piglets, their average daily gain was calculated from the results of weighing at birth, at the age of 14 days and at weaning, and the effect of terminal boars on this parameter was evaluated.

\section{Housing System and Feeding}

During gravidity, the sows were stabled in the same group pen and one week before farrowing they were transferred to farrowing house, where they were kept in individual farrowing pens with farrowing boxes. The pens were equipped with heated pads for piglets. Each pen was equipped with drinker and feed for piglets. The housing was in compliance with the COUNCIL DIRECTIVE 2008/120/EC. Ventilation in stables was automatic. Complete feed ration for sows was served moistened in amounts corresponding to their condition and number of piglets fed. Tab. I presents composition of feeding mixture for sows in farrowing house. From the fifth day of age, the piglets were fed ad libitum with a commercial type of complete feed ration for piglets with following components: oatmeal, lactose, toasted soybeans, soy protein concentrate, dextrose, fish meal, potato protein, fructose, coconut oil, monocalcium phosphate, dried sugar beet, inactivated yeasts, sodium chloride, seaweed meal, milk thistle seed.

\section{I: Composition of feed mixture for lactating sows}

\begin{tabular}{lc}
\hline \multicolumn{1}{c}{ Ingredients $(\% / \mathrm{kg})$} & Sows in farrowing house \\
\hline Wheat & 26 \\
Barley & 37.5 \\
Corn & 12 \\
Oat & 0 \\
Wheat bran & 0 \\
Soybean meal & 18 \\
Rapeseed extracted meal & 0 \\
Rapeseed oil & 2.5 \\
Minerals and vitamins & 4 \\
\hline
\end{tabular}

\section{Statistical Analyses}

The data were analysed in Statistica 12 software by two-factor analysis of variance with interaction between terminal boar and sex of piglets. Statistically significant differences were assessed using the HSD test for unequal n. All the differences were considered significant when $\mathrm{p}<0.05$.

\section{RESULTS}

Tab. II presents results of the observed effect of terminal boar and sex on individual weight of piglets. The experiment showed that terminal boar has a statistically significant effect $(\mathrm{p}<0.001)$ on individual weight of piglets from birth to weaning. The highest birth weight was recorded in piglets of the Pietrain and Duroc boars, with weight higher by $0.33 \mathrm{~kg}$ than in piglets of the $\mathrm{D} x \mathrm{Pn}$ hybrid combination. Weighing at the age of 14 days showed higher growth intensity in the piglets of the D boar, with weight higher by $0.16 \mathrm{~kg}$ then in the piglets of the Pn boar. The lowest weight was again found in the piglets of the $\mathrm{D} \times \mathrm{Pn}$ hybrid combination $(3.73 \mathrm{~kg})$. The same trend was observed at the time of weaning. The highest weaning weight was found in the piglets of the D boar $(7.24 \mathrm{~kg})$, followed by the 
II: The effect of terminal boar and sex on individual weight of piglets

\begin{tabular}{|c|c|c|c|c|c|c|c|c|}
\hline & & & \multicolumn{2}{|c|}{ Day $1(\mathrm{~kg})$} & \multicolumn{2}{|c|}{ Day $14(\mathrm{~kg})$} & \multicolumn{2}{|c|}{ Day $28(\mathrm{~kg})$} \\
\hline \multicolumn{2}{|l|}{ Factor } & $\mathrm{n}$ & Mean & SEM & Mean & SEM & Mean & SEM \\
\hline \multicolumn{9}{|c|}{ Individual factors } \\
\hline \multirow{3}{*}{$\begin{array}{l}\text { Terminal } \\
\text { boar }\end{array}$} & $\mathrm{D} x \mathrm{Pn}$ & 146 & $1.28^{b}$ & 0.02 & $3.73^{\mathrm{b}}$ & 0.07 & $6.31^{\mathrm{b}}$ & 0.12 \\
\hline & $\mathrm{D}$ & 41 & $1.51^{\mathrm{a}}$ & 0.02 & $4.50^{\mathrm{a}}$ & 0.16 & $7.24^{\mathrm{a}}$ & 0.23 \\
\hline & Pn & 119 & $1.52^{\mathrm{a}}$ & 0.03 & $4.34^{\mathrm{a}}$ & 0.09 & $7.11^{\mathrm{a}}$ & 0.13 \\
\hline \multicolumn{2}{|l|}{$\underline{\mathrm{p} \text {-value }}$} & & 0.000 & & 0.000 & & 0.000 & \\
\hline \multirow{2}{*}{ Sex } & B & 154 & 1.43 & 0.03 & 4.17 & 0.08 & 6.86 & 0.13 \\
\hline & G & 152 & 1.38 & 0.02 & 3.98 & 0.07 & 6.63 & 0.11 \\
\hline \multirow[t]{2}{*}{$\underline{p}$-value } & & & 0.620 & & 0.235 & & 0.414 & \\
\hline & \multicolumn{8}{|c|}{ Interaction of factors } \\
\hline \multirow{2}{*}{ D x Pn } & B & 66 & 1.29 & 0.04 & 3.83 & 0.12 & 6.40 & 0.21 \\
\hline & G & 80 & 1.28 & 0.03 & 3.66 & 0.09 & 6.24 & 0.14 \\
\hline \multirow{2}{*}{ D } & B & 22 & 1.51 & 0.03 & 4.61 & 0.22 & 7.33 & 0.32 \\
\hline & G & 19 & 1.51 & 0.03 & 4.37 & 0.25 & 7.13 & 0.34 \\
\hline \multirow{2}{*}{ Pn } & B & 66 & 1.54 & 0.04 & 4.36 & 0.12 & 7.17 & 0.18 \\
\hline & G & 53 & 1.50 & 0.04 & 4.32 & 0.12 & 7.05 & 0.19 \\
\hline $\mathrm{p}$-value & & & 0.868 & & 0.785 & & 0.987 & \\
\hline
\end{tabular}

D - Duroc, Pn - Pietrain, B - barrows, G - gilts

a, b: Means with different superscripts are significantly different at $\mathrm{p}<0.05$.

III: The effect of terminal boar and sex on average daily gain

\begin{tabular}{|c|c|c|c|c|c|c|c|c|}
\hline \multirow{2}{*}{ Factor } & & \multirow[b]{2}{*}{$\mathrm{n}$} & \multicolumn{2}{|c|}{ ADG Day 1-14 (g/day) } & \multicolumn{2}{|c|}{ ADG Day 15-28 (g/day) } & \multicolumn{2}{|c|}{ ADG birth - weaning (g/day) } \\
\hline & & & Mean & SEM & Mean & SEM & Mean & SEM \\
\hline \multicolumn{9}{|c|}{ Individual factors } \\
\hline \multirow{3}{*}{$\begin{array}{l}\text { Terminal } \\
\text { boar }\end{array}$} & $\mathrm{D} \times \mathrm{Pn}$ & 146 & $175.18^{b}$ & 4.51 & $184.02^{b}$ & 3,94 & $179.60^{\mathrm{b}}$ & 3.85 \\
\hline & $\mathrm{D}$ & 41 & $213.68^{\mathrm{a}}$ & 12.13 & $195.51^{\mathrm{a}}$ & 6,37 & $204.59^{a}$ & 8.41 \\
\hline & Pn & 119 & $201.48^{\mathrm{a}}$ & 5.04 & $197.87^{\mathrm{a}}$ & 4,83 & $199.68^{\mathrm{a}}$ & 4.26 \\
\hline p-value & & & 0.000 & & 0.069 & & 0.001 & \\
\hline \multirow{2}{*}{ Sex } & B & 154 & 195.64 & 5.12 & 192.37 & 4,09 & 194.01 & 4.20 \\
\hline & G & 152 & 185.43 & 4.54 & 189.50 & 3,86 & 187.46 & 3.62 \\
\hline $\mathrm{p}$-value & & & 0.238 & & 0,909 & & 0.435 & \\
\hline \multicolumn{9}{|c|}{ Interaction between factors } \\
\hline \multirow{2}{*}{ D x Pn } & B & 66 & 181.36 & 7.64 & 183.78 & 6,53 & 182.57 & 6.66 \\
\hline & G & 80 & 170.08 & 5.26 & 184.22 & 4,81 & 177.15 & 4.41 \\
\hline \multirow{2}{*}{ D } & B & 22 & 221.40 & 16.50 & 194.12 & 9,00 & 207.76 & 11.90 \\
\hline & G & 19 & 204.74 & 18.14 & 197.11 & 9,22 & 200.92 & 12.10 \\
\hline \multirow{2}{*}{ Pn } & B & 66 & 201.32 & 7.01 & 200.39 & 6,20 & 200.85 & 5.81 \\
\hline & G & 53 & 201.68 & 7.27 & 194.73 & 7,65 & 198.21 & 6.31 \\
\hline p-value & & & 0.626 & & 0.838 & & 0.960 & \\
\hline
\end{tabular}

D - Duroc, Pn - Pietrain, B - barrows, G - gilts

a, b: Means with different superscripts are significantly different at $\mathrm{p}<0.05$. 
piglets of the Pn boar $(7.11 \mathrm{~kg})$. The piglets of the D x Pn hybrid combination boar reached the lowest live weight at weaning $(6.31 \mathrm{~kg})$.

The experiment did not prove the effect of sex on individual weight of piglets, nevertheless, the differences between sexes are evident. All the weighing showed higher live weights in barrows than in gilts.

The effect of interaction between terminal boar and sex on individual weight of piglets was not statistically significant. However, there is an obvious tendency of highest birth weight in barrows of the Pn boar (1.54 kg) against the lowest birth weight in gilts of the D x Pn (1.28 kg).

Tab. III shows the results of effect of terminal boar and sex on average daily gain (ADG). A statistically significant ( $p \leq 0.001$ ) effect of terminal boar was proven for average daily gain of piglets from birth to weaning. In the interval from birth to the age of 14 days, the highest ADG was recorded in the piglets of the D boar $\left(213.68 \mathrm{~g} /\right.$ day). From the $15^{\text {th }}$ day of live to weaning, the highest ADG was found in the piglets of the Pn boar, higher by $2.36 \mathrm{~g}$ than in the piglets of the D boar. The highest ADG from birth to weaning was observed in the piglets of the D boar (204.59g/day). The piglets of the Pn boar reached average daily gain from birth to weaning of $199.68 \mathrm{~g} /$ day. The lowest ADG throughout the observed intervals was recorded in piglets of the D x Pn boar.

The effect of sex on average daily gain of piglets was not confirmed in the experiment, however, there are evident differences between the sexes in growth intensity. The barrows showed higher average daily gain than the gilts in all the intervals.

Effect of interaction between terminal boar and sex on average daily gain of piglets was not statistically significant, however there is an evident trend of highest ADG in barrows of the D boar in the interval from birth to the age of 14 days, while from the $15^{\text {th }}$ day of age to weaning, the fastest growth was observed in barrows of the Pn boar. From birth to weaning, the highest ADG was recorded in the barrows of the Pn boar. On the contrary, the lowest ADG was observed in the gilts of the D x Pn boar.

\section{DISCUSSION}

Birth weight is one of the factors that determine prosperity of piglets from birth to weaning (Škorput et al., 2018). Low birth weight can compromise not only the survivability rate, but also postnatal growth performance (Bee, 2007; Vaclavkova et al., 2012). This is confirmed also in the study by Vermeluen et al. (2016). Smith et al. (2007) state that piglets with birth weight below $1 \mathrm{~kg}$ have very small chance of survival until weaning and when they survive, they are most likely classified as non-standard pigs. Vermeluen et al. (2016) recorded average birth weight $1.30 \pm 0.34 \mathrm{~kg}$ and average live weight at weaning $6.28 \pm 1.35 \mathrm{~kg}$ in piglets of a Pietrain boar.
These values are lower by $0.22 \mathrm{~kg}$ in case of birth weight and by $0.83 \mathrm{~kg}$ in case of weaning weight when compared to the results of our experiment. Lower birth weight may be due to higher number of piglets in litter (Roehe and Kalm, 1997). Vermeluen et al. (2016) also emphasize, as well as other authors (Tribout et al., 2003; Vidović et al., 2012), a significant $(P<0.05)$ positive correlation ( $r=0.53$ ) between live weight at birth and live weight at weaning. Research by many authors (Lonergan et al., 2001; Edwards et al., 2006) has shown the advantage of the Duroc breed over other breeds, in terms of growth and subsequently of meat quality. Lower growth intensity in the Pietrain breed can be caused by lower accumulation of body fat in comparison with the Duroc breed (Edwards et al., 2006). Lukač et al. (2013) recorded weaning weight of $7.36 \mathrm{~kg}$ in piglets of a Duroc boar and the authors consider this weight optimal with positive effect on growth ability in later phases of fattening and better feed intake. At weaning, the pigs with weight bellow $3.6 \mathrm{~kg}$ require higher level of care and more complicated nutrition, which increases production costs for pork producers (Smith et al., 2007). Higher weaning weight also results in lower losses in later phases of fattening. Douglas et al. (2013) state that live weight at weaning or initial live weight at fattening has higher impact on growth performance when compared to live weight at birth. According to Lukač et al. (2013), threebreed crossbreeding can lead to more effective heterosis manifestations than crossbreeding of four or more breeds. This statement can explain why pigs of D x Pn hybrid combination boar, evaluated in this experiment, showed the lowest weights and growth intensity. However, some authors came to different conclusions. For example, Čechová (2006) documented higher birth weight in piglets of Pn $\mathrm{x}$ Hampshire hybrid combination boar than in piglets of the $\mathrm{D}$ boar. The results are uneven and obviously more factors play role, such as number of piglets in litter, nutrition and genetic basis of the animals. Average daily gain was higher in piglets with higher birth weight, which is in accordance with Fix et al. (2010) and Vázquez-Gómez et al. (2020). Evaluation of average daily gain revealed better growth intensity in the Duroc breed than in the Pietrain, mainly in the interval from birth to the age of 14 days, which may be explained by different approach in breeding. Fast growth of piglets of the D boar in the first two weeks of life may have a positive effect on survivability of piglets from birth to weaning. The difference between the sexes in individual live weight and average daily gain were not statistically significant, however, the barrows of all combinations were heavier on average and grew faster. Some studies found more pronounced differences between sexes of piglets in favour of barrows (Elbert et al., 2020), while some studies did not (Škorjanc et al., 2007). 


\section{CONCLUSION}

The experiment showed a statistically significant effect $(p<0.001)$ of terminal boar on individual live weight of piglets at birth, at the age of 14 days and at weaning. It also proved statistically significant $\left(p \leq 0.001\right.$ ) effect of terminal boar on average daily gain of piglets from birth to the $14^{\text {th }}$ day of life and on average daily gain of piglets from birth to weaning.

\section{REFERENCES}

BEE, G. 2007. Birth weight of litters as a source of variation in postnatal growth, and carcass and meat quality. Advances in Pork Production, 18: 191-196.

ČECHOVÁ, M. 2006. Analysis of some factors influencing the birth weight of piglets. Slovak Journal of Animal Science, 39(3): 139-144.

DEEN, M. G. H. and BILKEI, G. 2004. Cross fostering of low-birthweight piglets. Livestock Production Science, 90(2-3): 279-284.

DOUGLAS, S. L., EDWARDS, S. A., SUTCLIFFE, E., KNAP, P. W. and KYRIAZAKIS, I. 2013. Identification of risk factors associated with poor lifetime growth performance in pigs, J. Anim. Sci., 91(9): 41234132.

EDWARDS, D. B., TEMPELMAN, R. J. and BATES, R. O. 2006. Evaluation of Duroc- vs. Pietrain-sired pigs for growth and composition. J. Anim. Sci., 84(2): 266-275.

ELBERT, K., MATTHEWS, N., WASSMUTH, R. and TETENS, J. 2020. Effects of sire line, birth weight and sex on growth performance and carcass traits of crossbred pigs under standardized environmental conditions. Archives Animal Breeding, 63: 367-376.

FIX, J. S., CASSADY, J. P., HERRING, W. O., HOLL, J. W., CULBERTSON, M. S. and SEE, M. T. 2010. Effect of piglet birth weight on body weight, growth, backfat, and longissimus muscle area of commercial market swine. Livest. Sci., 127(1): 51-59.

HALEY, C. S., LEE, G. J. and RITCHIE, M. 1995. Comparative reproductive performance in Meishan and Large White pigs and their crosses. Animal Science, 60(2): 259-267.

KELLER, L. F. and WALLER, D. M. 2002. Inbreeding effects in wild populations. Trends in Ecology, 17(5): 230-241.

LONERGAN, S. M., HUFF-LONERGAN, E., ROWE, L. J., KUHLERS, D. L. and JUNGST, S. B. 2001. Selection for lean growth efficiency in Duroc pigs influences pork quality. J. Anim. Sci., 79(8): 2075-2085.

LUKAČ, D. 2013. Reproductive traits in relation to crossbreeding in pigs. Afr. J. Agric. Resh., 8(19): 2166-2171.

MARANDU, N., HALIMANI, T. E., CHIMONYO, M., SHONIWA, A. and MUTIBVU, T. 2015. Effect of withinlitter birth weight variation on piglet survival and pre-weaning weight gain in a commercial herd. J. Agric. Rural. Dev. in the Tropics and Subtropics, 116(2): 123-129.

McCANN, M. E. E., BEATTIE, V. E., WATT, D. and MOSS, B. W. 2008. The effect of boar breed type on reproduction, production performance and carcass and meat quality in pigs. Ir. J Agric. Food Res., 47(2): 171-185.

PEDERSEN, M. L. M., VELANDER, I. H., NIELSEN, M. B. F., LUNDEHEIM N. and NIELSEN, B. 2019. Duroc boars have lower progeny mortality and lower fertility than Pietrain boars. Transl. Anim. Sci, 3(2): 885-892.

ROEHE, R. and KALM, E. 1997. Efficient breeding on fertility should include birth weights. Schweinezucht und Schweinemast, 45(4): 38-40.

SMITH, A. L., STALDER, K. J., SERENIUS, T. V., BAAS, T. J. and MABRY, J. W. 2007. Effect of piglet birth weight on weights at weaning and 42 days post weaning. Journal of swine health and production, 15(4): 213-218.

SUREK, D., ALMEIDA, L. M., PANisSON, J. C., OLIVEIRA, S. G., ALBERTON, G. C., MAIORKA, A. and KRABBE, E. L. 2019. Impact of birth weight and daily weight gain during suckling on the weight gain of weaning piglets. Arquivo Brasileiro de Medicina Veterinaria e Zootecnia, 71(6): 2034-2040.

ŠKORJANC, D., BRUS, M. and ČANDEK POTOKAR, M. 2007. Effect of Birth Weight and Sex on PreWeaning Growth Rate of Piglets. Archives Animal Breeding, 50(5): 476-486.

ŠKORPUT, D., DUJMOVIĆ, Z., KAROLYI, D. and LUKOVIĆ, Z. 2018. Variability of birth weight and growth of piglets in highly prolific sows. Journal of Central European Agriculture, 19(4): 823-828.

TRIBOUT, T., CARITEZ, J. C., GOGUÉ, J., GRUAND, J., BOUFFAUD, M., BILLON, Y., PÉRY, C., GRIFFON, H., BRENOT, S., LE TIRAN, M. H., BUSSIÈRES, F., LE ROY, P. and BIDANEL, J. P. 2003. Estimation, par utilisation de semence congelée, du progrès génétique réalisé enFrance entre 1977 et 1998 dans la race porcine Large White: Résultats pourquelques caractères de production et de qualité des tissus gras et maigres. Journées de la Recherche Porcine en France, 36: 275-282. 
VACLAVKOVA, E., DANEK, P. and ROZKOT, M. 2012. The influence of piglet birth weight on growth performance. Research in Pig Breeding, 6(1): 59-61.

VÁZQUEZ-GÓMEZ, M., GARCÍA-CONTRERAS, C., ASTIZ, S., TORRES-ROVIRA, L., FERNÁNDEZ-MOYA, E., OLIVARES, Á., DAZA, A., ÓVILO, C., GONZÁLEZ-BULNES, A. and ISABEL, B. 2020. Piglet birthweight and sex affect growth performance and fatty acid composition in fatty pigs. Anim. Prod. Sci., 60(4): 573-583.

VERMEULEN, L., VAN BEIRENDONCK, S., BULENS, A., VAN THIELEN, J. and DRIESSEN, B. 2016. Sire line of pigs affects weaning weight, growth performance, and carcass characteristics of offspring. J. Anim. Sci., 94(10): 4360-4368.

VIDOVIĆ, V., LUKAČ, D., STUPAR, M., VIŠNJIĆ, V. and KRNJAIĆ, J. 2012. Heritability and repeatability estimates of reproduction traits in purebred pigs. Biotechnology in Animal Husbandry, 28(3): 455-462.

WOLTER, B. F., ELLIS, M., CORRIGAN, B. P. and DEDECKER, J. M. 2002. The effect of birth weight and feeding of supplemental milk replacer to piglets during lactation on preweaning and postweaning growth performance and carcass characteristics. Journal of Animal Science, 80(2): 301-308.

Contact information

Jan Lujka: jan.lujka@mendelu.cz (corresponding author)

Pavel Nevrkla: pavel.nevrkla.uchhz@mendelu.cz

Zdeněk Hadaš: zdenek.hadas@mendelu.cz 